\title{
ЛИТЕРАТУРОВЕДЕНИЕ
}

\author{
Г.Р. Консон
}

\section{ОБРАЗ ДЬЯВОЛА В ЛИТЕРАТУРЕ КАК СИМВОЛ НАДВИГАЮЩЕГОСЯ КАТАСТРОФИЗМА}

\begin{abstract}
Аннотация. Предметом исследования являются образы дьявола в классической литературе, почерпнутые, с одной стороны, из сказочного фольклора и литературной фантастики, а с другой оказываются порождением сознания самого человека. Введение образа демона в художественное произведение стало одним из концептуальных симптомов угрозы для человеческой жизни. Его появление обычно сопровождалось всевозможными происшествиями, а в драматургии производило дерзновенное, взрывчатое впечатление. Данные соображения побудили их автора детально исследовать так называемую демоническую традицию ряда выдающихся литературных произведений.

Для рассмотрения данной темы применяется метод психологического анализа, основанный на выявлении сформулированного М. Уваровым бинарного архетипа, выстраивающегося здесь на базе близнечного эфрректа человека-дьявола.

Новизна исследования состоит в выявлении основного источника психологических сношений человека с дьяволом - продажи души, которая, как показывает автор статьи, в каждом случае имеет свою тарификацию, что в конечном счёте обнажает степень переживаемого человеком чувства катастрофизма. Автор также раскрывает разнообразную мотивацию подобной продажи, на основе которой выявляется нравственное крушение личности, за чем следует её неизбежное физическое уничтожение.

В статье показано, что образы дьявола, воплощённые в рассмотренных нами художественных произведениях, являются не чем иным, как фантазией бунтующего против действительности человека, своеобразной модальностью его духа, имплицитно заложенной в нём само́м и выплёскивающейся наружу в зависимости от его эмочионально-психологического состояния.

По результатам проведённого в исследовании обзора различных трактовок в понимании явлений катастрофизма, выраженных в искусстве посредством деперсонализации личности, автор считает возможным сделать вывод о том, что история человечества основана на его отношении к трансценденции, неразрывно связанном с моральными устоями самого человечества. При нарушении этих устоев трансценденция в его сознании начинает конкретизироваться и тем самым вочеловечиваться, приобретая реальную силу катастрофического ожидания нравственного возмездия и его свершения.
\end{abstract}

Ключевые слова: человек, дьявол, чёрт, демонический, Мефистофель и Фауст, бинарный архетип, катастрофа и катастрофизм, образ, продажа души, сознание.

H а рубеже XX-XXI веков обострились эсхатологические вопросы, которые, хотя изначально и были связаны с мифологией и богословием, в настоящее время приобрели реальную жизненную значимость. С. Сморжко пишет, что «каждая мифологическая традиция, создавая свою модель мироздания, указывает на определённые границы, за которыми эта традиция переживает катастрофу, исчезает или меняется. Эсхатологические мотивы всегда появляются там, где “этому миру" начинает грозить гибель - иногда окончательная, не предусматривающая восстановления, иногда предполагающая переход на новый качественный уровень... Апокалипсис - суд над миром, смерть, а часто и преображение всего бытия. Но есть и “личный Апокалипсис" - смерть отдельного человека, неизбежно ставящая вопрос о том, что происходит за границами жизни, проходящей в теле»1.

\footnotetext{
1 Сморжко С. Художественная эсхатология в романах Ф.М. Достоевского 1860-1870-х годов. Дисс. ... канд. филол. н. Краснодар, 2007. 201 с. (URL: http://www.dissercat.
} 
Источником такого Апокалипсиса, как правило, является сам человек, а, точнее, его моральная основа ${ }^{2}$ В случае её разрушения у человека искажается сознание, в котором возникает деформированная картина мира ${ }^{3}$. Такой синдром может сопровождаться галлюцинаторными явлениями, содержанием которых становятся всевозможные потусторонние видения, где центральные образы - черти, демоны, бесы, дьяволы - почерпнуты из сказочного фольклора и литературной фантастики. Вместе с тем всё бесовское фактически есть порождение раздвоенного сознания человека и потому находится в нём самом.

В связи с этим выявление опасностей для человечества лежит в сфере исследования его потенциальных нравственных сил, в результате чего возможно предотвращение явления катастрофизма ${ }^{4}$.

com/content/khudozhestvennaya-eskhatologiya-v-romanakhfm-dostoevskogo-1860-1870-kh-godov. [Дата обращения: 26.09.2013]).

2 Н. Чернышевский, исследуя античное понимание трагического, в качестве образца приводит сложившуюся в древнегреческой эстетике максиму: «в характере великого человека ... всегда есть слабая сторона; в действовании замечательного человека есть всегда что-нибудь ошибочное или преступное. Эта слабость, проступок, преступление губят его. А между тем они необходимо лежат в глубине его характера, так что великий человек гибнет от того же самого, в чём источник его величия» (Чернышевский Н.Г. Эстетические отношения искусства к действительности // Чернышевский Н.Г. Собрание сочинений в 5-и тт. М., 1974. Т. 4. С. 35). О том, что люди сами являются источниками своей гибели, писал Л. Скрягин (см.: Скрягин Л. Тайны морских катастроф. 2-е изд. М., 1986. С. 4).

Е. Положенцева считает, что «для сознания этого типа характерно интеллектуальное и остроэмоциональное восприятие процесса упадка культуры, разрушения её базовых ценностей, невозможности найти эффективные средства для стабилизации ситуации и “спасения" культурного ядра общества» (Положенцева Е. Культурные ориентиры катастрофического сознания: Дисс. ... канд. филос. наук. Ростов н/Д: Ростовский государственный университет, 2003. 151 с. (URL: http://www.dissercat.com/content/kulturnye-orientirykatastroficheskogo-soznaniya). [Дата обращения: 30.12.2012]).

4 По справедливому мнению О. Теняковой, «будущность человечества должна быть связана с новыми цивилизационными и нравственными принципами, выработкой “стратегии спасения” планетарного сообщества, поиском выхода на пути устойчивого развития цивилизации» (Тенякова О.М. Катастрофизм как мегатенденция современного цивилизационного развития. Дисс. ... канд. филос. наук. Уфа: Башкирский государственный университет, 2003. 180 c. (URL: http:// www.dissercat.com/content/katastrofizm-kak-megatendentsiyasovremennogo-tsivilizatsionnogo-razvitiya). [Дата обращения: 05.04.2013]).

\section{1. Трактовка образа гётевского Мефистофбеля}

Введение образа демона в художественное произведение - один из концептуальных симптомов угрозы для жизни человека, появление которого обычно сопровождалось всевозможными происшествиями, а в драматургии производило дерзновенное, взрывчатое впечатление. Нередко этот образ являлся продолжением народно-сказочных традиций (Гоголь), романтических (Байрон, Лермонтов, Врубель), философских (Гёте). И. Ильин выводит даже своеобразную историю культуры «демонизма». По наблюдению философа, с начала XIX века в европейском искусстве появляется «демонизм сомнения, отрицания, гордости, бунта, разочарования, горечи, тоски, презрения, эгоизма и даже скуки... Байрон, Гёте, Шиллер, Шамиссо, Гофман, Франц Лист, а позднее Штук, Бодлер и другие развёртывают целую галерею "демонов" или “демонических" людей и настроений, причём эти “демоны” - “умны”, “остроумны”, “образованы”, “гениальны”, “темпераментны”, словом "обаятельны” и вызывают сочувствие, а "демонические люди" являются воплощением “мировой скорби”, “благородного протеста" и какой-то “высшей революционности”» 5 .

Пушкин, как отмечает Г. Васильева, в своём стихотворении «Сцена из Фауста» в каждом действии Мефистофеля видел его «отрицательное самоопределение через противополагание я и не-я» ${ }^{6}$.

B XX веке к романтическим характеристикам лукавого прибавились новые черты. Томас Манн в романе «Доктор Фаустус» называет его «пройдохой», «лжецом», «жуликом», «пошляком», «глупцом», «тварью» и даже «сутенёром». Пошлого чёрта, выведенного в произведениях Достоевского и Чехова, также видят А. Николова и О. Боброва.

\footnotetext{
5 Ильин И.А. О грядущей России: К истории дьявола (20.10.1948 г.) // Избранные статьи / Под ред. Н.П. Полторацкого. Изд. Св.-Троицкого Монастыря и Корпорации Телекс Джорданвилл, Н.-Й. США, 1991. М.: Воениздат, 1993. 368 с. (URL: http://lib.ru/POLITOLOG/IILIN/istoii.txt. [Дата обращения 22.05.2012]).

6 Васильева Г. К истории «Замысла о Фаусте» А.С. Пушкина // Наука. Университет. 2000. Материалы Первой научной конференции. Новосибирск, 2000. C. 64-69 // philology.ru: Русский филологический портал. (URL статьи: http://www.philology.ru/ literature2/vasilyeva-00.htm. [Дата обращения: 17.11.2012]).

Николова А., Боброва О. Образ пошлого чёрта в творчестве Ф.М. Достоевского и А.П. Чехова. (URL: http://web.znu. edu.ua/herald/issues/2008/fil_2008_1_2/2008-26-06/022.pdf. [Дата обращения: 01.06.2012]).
} 


\section{Филология: научные исследования 2(14) 2014}

В исследовании Н. Лейтес образ Мефистофеля осмыслен как символический, причём с ярко выраженной индивидуальностью. Она пишет, что Мефистофель - «умный, смелый, находчивый, озорной, он в то же время может быть безжалостным, беспощадным» [не слишком ли много для символического образа в одном существе? - Г.К. $]^{8}$. При этом Лейтес выявляет в нём конкретные стороны гётевских современников. Духовные черты поэт заимствовал у Иоганна Готфрида Гердера, а остроумие - у одного из своих близких друзей Генриха Мерка9.

А. Аникст считает Мефистофеля «принципом в обличии», который «напоминает человека, но с поправкой на черты дьявольщины, взятые из старинных поверий и иронически добавленные к его характеристике, потому что Гёте совсем не стремится уверить читателей, будто это настоящий чёрт. Мефистофель - чёрт литературный, философский, но никак не чёрт средневековых поверий» ${ }^{10}$.

Г. Васильева в Мефистофеле, отдавая должное его возможностям логического мышления, выявляет в нём также коннотацию образа ветхозаветного Змия, идею совращения «садами земных наслаждений». В качестве таких удовольствий она выделяет мефистофельское предложение своего варианта «ars amandi, науки любви», своего собственного «культа sensualite» ${ }^{11}$.

Г. Крауклис, исходя из листовской трактовки Мефистофеля в симфонии «Фауст», видит в этом «ненастоящем» чёрте концентрацию «всего тёмного и низменного в человеке, это - неверие в идеалы, это - скепсис, цинизм» ${ }^{12}$.

Итак. Бунтарь, гений, мудрец, логик, эрудит, ярко выраженный индивидуалист, скептик, двигатель прогресса, страдалец, имеющий своё собственное представление о любви, гордец, острослов,

\footnotetext{
8 Лейтес Н. От «Фауста» до наших дней: Из истории немецкой литературы. М., 1987. С. 26.

9 См.: Там же. С. 26.

10 Аникст А. Творческий путь Гёте. М., 1986. С. 385.

11 Васильева Г. К истории «Замысла о Фаусте» А.С. Пушкина // Наука. Университет. 2000. Материалы Первой научной конференции. Новосибирск, 2000. С. 64-69 // philology.ru: Русский филологический портал. (URL статьи: http://www. philology.ru/literature2/vasilyeva-00.htm. [Дата обращения: 17.11.2012]).

12 Крауклис Г. Сюжеты и образы Гёте в западноевропейском программном симфонизме XIX в. // Гётевские чтения: 1993 / Под ред. С. Тураева. М., 1994. С. 165.
}

властитель человеческих душ, эгоист, искуситель, совратитель, циник, киллер, пошляк, пройдоха, лжец, жулик, глупец, тварь, сутенёр, смелый, находчивый, озорной, безжалостный, средоточие всего тёмного и низменного, беспощадный, аналог ветхозаветного Змия, похожий на человека принцип в обличии, но с поправкой на дьявола, тем не менее, с чертами конкретно-исторических личностей, отрицательное самоопределение в раздвоении на «я» и «не-я». Добавим к этому и ранее упомянутое, исходящее из него обаяние, - что это за многоликое существо, время от времени напоминающее о себе в литературе? Действительно ли оно негативно? Л. Романчук и Д. Щитов пишут, что «уже в эпоху предромантизма зло становится всё более неоднозначным, вызывая вопрос: так ли уж оно плохо?, а добро - всё более пресным, слабым, колеблющимся и потому проигрывающим в схватке с непреклонной волей “зла"» ${ }^{13}$.

Мефистофель Гёте в трагедии «Фауст» представлен как философ с ироничным складом ума, диалектично мыслящий, нелишённый обаяния. Зло он понимает как необходимую составляющую в созидании добра. Поэтому в нём на первый план выступают люциферические энергии. При этом он традиционно лжив, в частности прикидывается дружелюбным к Фаусту. Но его коварные планы уничтожить его раскрываются в диалоге с самим с собой (после получения расписки учёного).

Мефистофель передёргивает значение света как такового, развенчивает его как самостоятельный феномен, приписывает ему метафорически агрессивные черты, утверждая его производность от тьмы. Показывает пустоту, несостоятельность и беспомощность света. Является типичным чёртом-критиканом. Преследует цель разрушения, не делая исключения и для себя, в чём сказывается некая усталость от жизни (типично романтический мотив).

Чёрт скромен по убеждению. Досадует на материальный мир, который противостоит его козням. Переживает, что не сжил со свету весь людской род, на этой почве чуть с ума не сходит от тоски. И, тем не менее, Мефистофель - оптимист.

Не веря людям, требует от Фауста расписку, предлагая, однако, нечестную игру, построенную на неравных условиях: сам он завоёвывает фаустов-

13 Романчук Л., Щитов Д. Демонизм. Зверь Апокалипсиса: Литературные мифы, версии, реалии / Предисл. А. Михалёва. M., 2012. C. 22. 


\section{Литературоведение}

ское доверие службой, а документ о продаже души учёный должен написать кровью.

Мефистофель напутствует Фауста жить вне морали. Отрицает человеческие силы, разум, приветствует только ложь. Иронично относится к богословию, к медицине и любви. Не имеет представления о науках, что проявляется в беседе со студентом. Возмущён жадностью церкви.

Однако Бог, отправляя Мефистофеля соблазнить Фауста, ценит его более других духов отрицания, считая его весёлым плутом, который не даёт человеку пребывать в застое и впадать в спячку (Пролог).

Фауст считает Мефистофеля мелким вредителем, который не справился с разрушением вселенной, и потому завистливым и злобным пройдохой.

Подобное расхождение в восприятии Мефистофеля говорит о его особом свойстве - подлаживании под того, с кем он общается, о готовности отказаться от своего «я».

Будучи уверен, что Фаусту достаточно самых элементарных плотских радостей, Мефистофель ведёт его «на экскурсию»:

- $\quad$ в кабачок с надеждой, что философ упьётся вином и забудет о своих поисках смысла жизни;

- в кухню ведьмы, а затем на шабаш ведьм в Вальпургиеву ночь с целью возвратить ему молодость, дать возможность испытать чувственные наслаждения и отвлечь от возвышенных исканий;

- $\quad$ сводит с Маргаритой, чтобы удовлетворить его чувственные желания.

Подобные попытки соблазнить Фауста говорят и о примитивном представлении Мефистофеля, касающемся духовных запросов человека, и о низком духовном уровне чёрта. Поэтому все его потуги обольстить учёного терпят крах. Философа не интересуют низменные устремления, даже его первоначально чувственное влечение к Гретхен перерастает в любовь. Сверх того, потеря Маргариты обогащает его духовным жизненным опытом.

Тем не менее, на наш взгляд, Мефистофель является своеобразным продолжением Фауста. Внешне его можно принять за фаустовского дуала ${ }^{14}$. К такому

14 Дуальные отношения - «это отношения полного психологического дополнения. Являются наиболее оптимальными для обеспечения жизнедеятельности индивида. Эти отношения - самые удобные, там не нужно приспосабливаться друг к другу. Общаясь с дуалом, человек может оставаться самим собой. Происходит естественное, самой природой обусловленное разделение обязанностей, и человек в такой паре по- рядоположению провоцируют некоторые сходные качества характеров Фауста и Мефистофеля:

- Фауст стремится познать мир, Мефистофель уже его знает (Фауст в идеальном будущем);

- Фауст горько сетует на несовершенства в мире, придя к такому разочарованию в конце своей жизни, Мефистофель со знанием дела критикует мир изначально;

- Фауст хочет познать любовь, но это познание невозможно без свершения ошибок, а в иных случаях и без преступлений. В жизни Маргариты он становится невольным и косвенным её убийцей. Мефистофель для достижения цели идёт на любые преступления.

Как видим, в сравнении Фауста с Мефистофелем раскрываются два отношения к миру - относительное (человеческое, рефлектирующее, сопровождающееся ошибками и покаянием) и абсолютное (инфернальное, жёсткое, безжалостно устраняющее помехи, чуждое к раскаянию). Поэтому их отношения представляются более сложными, чем при первоначальном знакомстве. В действительности в них сказывается близнечный феномен ${ }^{15}$, основанный на явлении бинарного архетипа (проявившегося здесь в оппозиции человека-дьявола) ${ }^{16}$ и свя-

лучает возможность заниматься посильным и интересным для себя делом. В дуальных парах редко возникают конфликты, а если и возникают, то быстро и безболезненно разрешаются. Партнеры подходят друг к другу как две половинки разорванной фотографии, вместе составляющие одно целое» (Гуленко В., Молодцов А. Введение в соционику. К., 1993 // Мы - дуалы: Соционический клуб. (URL статьи: http://dual. com.ua/publ/5-1-0-172). [Дата обращения: 04.01.2014]).

15 Истоками такого феномена оказываются близнечные мифы и мифы о душе, которые при помощи современных данных археологии, этнографии, мифологии, фольклористики и лингвистики позволяют предполагать «зарождение у первобытного Нomo sapiens сложной системы верований, обычаев и обрядов, опирающихся на идею о соединении в человеке 2 различных начал: души и тела (см. Анимизм, Дуализм, Психофизическая проблема). Говоря языком немецкой классической философии, осознавшая себя душа первобытного человека возвысилась до состояния духа» (Человекознание // Большой психологический словарь / Сост. Б. Мещеряков, В. Зинченко. М., 2004. (URL: http:// vocabulary.ru/dictionary/30/word/chelovekoznanie). [Дата обращения: 15.06.2013]).

16 Бинарный архетип основан на взаимосвязанной оппозиции явлений, это «уникальный логический подтекст европейской культуры, присущий ей изначально. В XX в. понимание антиномических ситуаций в качестве некоего “разлома" культуры, способа риторически-безответного вопрошания приобретает трагические формы альтерна- 


\section{Филология: научные исследования 2(14) • 2014}

занный с характерной для европейской культуры традицией «двойничества» ${ }^{17}$.

В этой традиции М. Уваров выявляет три типо-

вые закономерности:

- «идея бинарного архетипа структурирует целый спектр многовариантных практик антиномического, амбивалентного типа, являясь последовательным философским оформлением этой проблемы;

- истоки проблемы бинаризма лежат в мифолого-этнографической сфере - значимом провозвестии европейской культуры, что находит своё выражение в проблеме структурных (бинарных) оппозиций, близнечного культа, полисемантических структур культурно-исторического бытия;

- бинарный архетип является своеобразным семиотическим "кодом" классической европейской культуры, стержнем проблематизации мышления, ядром дискурсивных практик парадоксально-апоретического типа» ${ }^{18}$.

Сформулировав эти закономерности, учёный приходит к выводу, что бинарные отношения «изначально заложены в природу философской рефлексии» и что «проблема бинарного архетипа является катализатором наиболее уязвимых, “больных"

тивного стиля мышления, не признающего никаких форм синтеза. В этом аспекте необходимо исследовать такие феномены культуры XX в., как амбивалентное (бидоминантное) сознание, в частности, идею антиномий мышления; структуру “атактического синдрома” разорванного сознания; парадокс “мультипликации” (самовоспроизведения) тоталитарных структур; дилеммы современного религиозного сознания и др.» (Бинарный архетип // Библиотека учебной и научной литературы. (URL: http://sbiblio.com/ biblio/archive/uvarov_binarniy/00.aspx). [Дата обращения: 11.06.2013]).

17 Истоками такого феномена, по наблюдению М. Уварова, служат «диалоговая форма платоновских текстов, метод “Да и Нет” П. Абеляра, тема двойников в творчестве Ф.М. Достоевского, М.М. Бахтина и М. Бубера, идея “зеркала” в психоаналитической концепции Ж. Лакана... «"мистическая” связь, существующая между европейским и русским самосознанием. Трагизм близнечной ситуации, другими словами, выражает не просто парадоксальность развития, эволюции культурно-исторических типов рациональности, но и конкретные парадоксы истории культуры» (Уваров М. Бинарный архетип // СОФИК: Центр современной философии и культуры имени В.А. Штоффа Санкт-Петербургского Философского общества. (URL статьи: http://sofik-rgi.narod.ru/avtori/binarniy_ arxetyp/01_1.htm). [Дата обращения: 11.06.2013]).

18 Там же. аспектов философского, этико-религиозного, художественного и научного творчества» ${ }^{19}$.

Исходя из этих положений, попытаемся рассмотреть бинарный архетип человека-дьявола $в$ наиболее уязвимых точках их соотношений, с особой остротой выявляющихся во время переживаний личностью чувства катастрофизма.

\section{2. Образ дьявола в прочзведениях Пушкина}

Мощным источником в традиции появления образа чёрта или превратившегося в него человека служит творчество А.С. Пушкина. В его произведениях «Борис Годунов», «Пиковая дама», «Дон Жуан», «Сказка о попе и его работнике Балде», «Моцарт и Сальери», «Сказка о Золотом петушке» созданы многообразные ситуации продажи такого уникального, отнюдь не предназначенного для неё товара как человеческая душа.

1. «Сказка о попе и его работнике Балде», в сущности, основана на коммерческо-бытовом варианте продажи души хозяина за неуплату работнику жалованья.

2. «Борис Годунов» - продажа души состоялась ещё как бы до начала произведения. Видение царю Борису в углу окровавленного дитяти (образец раздвоенного сознания) - это совестное возмездие за предполагаемый коммерческополитический договор в государственном масштабе.

3. Трагедия «Пиковая дама»:

a) приход Германна к графине, фактически предлагающего продать свою душу и продающего её за возможность обогащения - обслуживание навязчивой идеи наполеонизма (manía grandiosa) как темы власти над людьми ${ }^{20}$;

б) явление графини-дьявола Германну (образец раздвоенного сознания) знаменует его совестное наказание ${ }^{21}$.

\footnotetext{
19 Там же.

20 Дьяволизм Германна Ю. Селезнёв видит в том, что он заклинал графиню «не только всем святым, но и всем греховным... и это обещание не осталось там без внимания. Герман “продал душу дьяволу” за тайну достижения денег» (Селезнёв Ю. В мире Достоевского. М., 1980. С. 163. [Библиотека «Любителям российской словесности]).

21 По мнению Ю. Селезнёва, то, что мёртвая графиня насмехается над Германном, - это «тайный знак дьявола»: она «уже мёртвая, насмешливо взглянула на Германа, “прищуривая одним глазом"». (Там же. С. 165).
} 
4. Трагедия «Дон Жуан»:

a) продажа души дьяволу за любовные наслаждения (контракт с сатаной на поиски идеала состоялся как бы до начала трагедии).

б) продажа души наказуется приходом к Дону Жуану статуи Командора (семантика дьявола и мотив раздвоения сознания) - нравственное возмездие.

5. «Сказка о Золотом петушке» - душа продаётся двум дьяволам:

a) старику Звездочёту за обеспечение спокойной сытой жизни (государственный пакт о ненападении и бескровной защите отечества);

б) Шемаханской девице за фантастическую любовь - мотив Фауста (брачный контракт, основанный на псевдопоэтичных отношениях, обеспеченный предательством памяти своих сыновей).

6. «Моцарт и Сальери» - продажа души дьяволу из зависти к гениальному коллеге под предлогом «во имя искусства» 22 .

В суммировании разновидностей сделок героя с дьяволом, воплощённых в произведениях Пушкина, нам представляется весьма многообразная картина по продаже человеческих душ, где были намечены основные модели мотиваций и купчих документов:

- коммерческо-бытовая сделка, а в конечном счёте контрактно-бытовые отношения артиста с импресарио (поп и работник Балда), конкретизированные мотивом «во имя искусства» (Сальери);

- коммерческо-политический пакт в государственном масштабе ради власти (Борис Годунов), ради застойной и безопасной жизни (царь Додон);

22 Е. Мелетинский считает, что Сальери отравляет Моцарта «как бы во имя вечного искусства, т. е. ради идеи, приближаясь тем самым к “теоретикам” Достоевского, но также терпит моральное поражение: “И я не гений? Гений и злодейство две вещи несовместные”. Психологической основой преступления Сальери выступает зависть, которую он пытался в себе отрицать (ср. со сверхчеловеческими претензиями Раскольникова, осуждением индивидуалистической морали Раскольникова и Ивана Карамазова у Достоевского). Разумеется, “теория” у Сальери не достигает таких философских высот, как у персонажей Достоевского, ибо Сальери убивает Моцарта, так как именно с существованием Моцарта на земле он не может смириться; и одновременно философия Сальери останавливается на общечеловеческом уровне, без социального обострения» (Мелетинский Е. Заметки о творчестве Достоевского. М., 2001. С. 24).
- карьерно-финансовый договор за возможность приобретения статуса сверхчеловека ${ }^{23}$ (Германн);

- брачный контракт с дьяволом, основанный на квази-поэтичных отношениях и забвении близких (царь Додон) или измене (Дон Жуан).

В приведённых примерах показан, во-первых, основной источник сношений человека с дьяволом, каким оказывается факт продажи человеческой души, которая в каждом приведённом случае имеет свою тарификацию, что в конечном счёте обнажает степень переживаемого человеком чувства катастрофизма;

а во-вторых - раскрываются многообразные психологические мотивы предательства своего «я», на основе которых выявляется нравственное крушение личности, за что её настигает неминуемое возмездие - физическое уничтожение.

\section{3. Образ нечистой силы в творчестве Гоголя}

В многообразном калейдоскопе ликов дьявола, встречающихся в творчестве Гоголя, выделим наиболее характерные тенденции. Одна из них собственно сатанинская, мистическая, наважденческая, которая вторгается в мир человека извне. Она конфликтна ему, и человек ведёт посильную с ней борьбу ${ }^{24}$. Истоком этой тенденции является мифологический тип мышления ${ }^{25}$. В отмеченной тенден-

23 Понятие сверхчеловека, принадлежащее А. Ницше, необычайно точно охарактеризовал К. Ясперс: «Атеист Ницше выдвинул новую цель - сверхчеловека; эта мысль стала апофеозом культа власти и силы, руководством к выведению лучшей человеческой породы, к просветлению жизни и претворению её в дионисическую реальность» (Ясперс К. Ницше и христианство / Пер. с нем. Т. Бородай. М., 1994. С. 107). Несмотря на то, что оно возникло в более позднее время, мы используем его для выражения тех глобалистских планов, которыми герои преисполнены в своих устремлениях.

24 По мнению Л. Чернова, «демонология Гоголя - это описание отрицательных черт внутри самого человека. При этом - бесовщина Гоголя остаётся религиозно онтологической, т.е. непосредственно овеществлённой, воплощённой. Таким своим качеством, тем, что называется действительной фантасмагорией, мистикой, - Гоголь отличен от Достоевского, который бесовщину психологизирует и социологизирует» (Чернов Л. Гоголь и юродство. (URL: http://www. davidsbuendler.kz/node/179)).

25 Е. Корнилова считает, что «мифологическому мышлению обычно способствуют два фактора: неизбежная неточность, субъективность и стремление найти аналогии с уже известным при формировании в человеческом сознании представлением об объективной реальности, во-первых; и, 


\section{Филология: научные исследования 2(14) • 2014}

ции есть разветвление на комедийный образ мелкого чёрта, встречающегося в «Вечерах на хуторе близ Диканьки», «Нос» и всемогущего, устрашающего демона («Вий»).

Другая тенденция исходит из сознания человека. Назовём её антропо-бесовская, когда демоническое начало заложено в индивиде и служит средством для выявления его облика ${ }^{26}$. Тенденция эта выражена в негативных качествах его характера, в котором доминирующую роль играет ложь, дающая её пользователю неограниченные, подобно дьяволу, права над окружающими. Инфернальное, проявленное во лжи, оказывается пустым и банальным $^{27}$, «вечной плоскостью» и «вечной пошлостью» (Д. Мережковский). Классические образцы такого характера - фигура Чарткова ${ }^{28}$, шаржированные образы одушевлённого Носа (беседа с ним майора

во-вторых, способность человеческого мозга произвольно комбинировать элементы представлений, создавая несвойственные реальности сочетания» (Корнилова Е. Мифологическое мышление и мифопоэтика западноевропейского романтизма. Дисс. ... д-ра филол. наук. М., 2002. 281 с. (URL: http://www.dissercat.com/content/mifologicheskoe-soznanie-imifopoetika-zapadnoevropeiskogo-romantizma). [Дата обращения: 28.12.2012]).

26 Поводом к этому служит гипербола какой-нибудь черты характера. В. Брюсов писал, что у всех героев Гоголя «чудовищно, несоразмерно развита одна часть души, одна черта психологии. Создания Гоголя - смелые и страшные карикатуры, которые, только подчиняясь гипнозу великого художника, мы в течение десятилетий принимали за отражение в зеркале русской действительности» (Брюсов В. Гипербола и фантастика у Гоголя. (URL: http://az.lib.ru/b/brjusow_w_j/ text_0280.shtml). [Дата обращения: 17.11.2012]).

27 См.: Вулис А.З. Роман М. Булгакова «Мастер и Маргарита». М.: Художественная литература, 1991. 224 с. [Серия «Массовая историко-литературная библиотека»]. С. 63.

28 Е. Лившиц в такой трактовке инфернального у Гоголя находит в качестве источника мотивы готического романа: «Мельмот продаёт душу дьяволу, чтобы получить взамен сверхъестественые возможности, его толкнула на этот шаг “бесплотная и неистовая пытливость ума"..., которую он на закате своих дней видит в своём потомке; Чартков губит свой талант во имя более прозаических предметов и получает деньги и славу модного живописца; таким образом, “фаустовский” пласт романа совершенно игнорируется... Гоголь читает “Мельмота” и “Исповедь” как готические романы, идя, таким образом, вслед за В. Скоттом, упоминавшим о Метьюрине как о “последователе г-жи Радклиф”» (Лившиц Е. Английский контекст творчества Гоголя: Н.В. Гоголь и Ч.Р. Метьюрин. Дисс. ... канд. филол. наук. М., 2001. 221 c. (URL: http://www.dissercat.com/content/angliiskii-konteksttvorchestva-gogolya-n-v-gogol-i-ch-r-metyurin). [Дата обращения: 28.12.2012]).
Ковалёва - вполне убедительный вариант раздвоенного сознания) ${ }^{29}$, Чичикова, Хлестакова ${ }^{30}$.

Третья тенденция связана с коллективным воображением, овеянным фольклорным шармом, что служит поэтизации народного быта («Вечера на хуторе близ Диканьки») ${ }^{31}$.

Четвёртая возникает в результате показа массового мышления, того мира, который выбирает себе соответствующего героя или, скорее, эрзацгероя, каким являются Чертокуцкий, Хлестаков и Чичиков ${ }^{32}$.

29 М. Бахтин считает, что нос и рот исполняют ведущую роль в гротескном изображении тела. По его мнению, «именно они подвергаются преимущественному положительному преувеличению - гиперболизации; они могут даже отделяться от тела, вести самостоятельную жизнь, так как они заслоняют собой остальное тело как нечто второстепенное (обособиться от тела может отчасти иное)» (Бахтин М. Творчество Франсуа Рабле и народная культура средневековья и Ренессанса. 2-е изд. М., 1990. С. 352).

30 В. Брюсов считает, что «смешная сторона человеческих отношений в них преувеличена до крайности; нелепость в них доведена до какого-то культа» (Брюсов В. Гипербола и фантастика у Гоголя. (URL: http://az.lib.ru/b/brjusow_w_j/text_0280. shtml). [Дата обращения: 17.11.2012]). Однако смешное здесь не так уж безобидно. По мнению Л. Чернова, «ложь Хлестакова имеет силу, она делает своё дело, ведь Хлестакову верят. И благодаря силе этой лжи Хлестаков становится демиургом, творцом окружающей реальности. И совсем не важно, что слушатели Хлестакова - лопоухие провинциалы, легковеры. А над ними, как правило, и смеются зрители с читателями. Важно то, что он строит окружающий мир по своим собственным законам, по законам лжи и иллюзии. И совсем недаром один из персонажей пьесы произносит: “Страшно просто. А отчего - и сам не знаешь”. А страшно оттого, что подобного рода иллюзию нельзя сотворить человеческими силами. Разросшийся до гигантских размеров Хлестаков это и Кириллов Достоевского, и чёрт-собеседник Ивана Карамазова и президент европейских штатов из повести об Антихристе В. Соловьёва» (Чернов Л. Гоголь и юродство. (URL: http://www.davidsbuendler.kz/node/179)).

31 Источником такой тенденции является склад характера самого Гоголя, который отличался повышенной мечтательностью. В. Розанов пишет, что он был великим платоником, бравшим «всё в идее, в грани, в пределе (художественном)...» (Розанов В. Легенда о Великом инквизиторе Ф.М. Достоевского // ВЂхи: Библиотека русской религиозно-философской и художественной литературы. (URL: http:// www.vehi.net/rozanov/legenda.html). [Дата обращения: 22.09.2012]). Поэтому фантастика Гоголя кажется, согласно Брюсову, «как бы реальнее самой реальности».

32 Известно, что суть концепции Гоголя в том, как «мир создаёт себе судью по своему образу и подобию и соблазняется им, раскрываясь в последней своей наготе, бесстыдно “заголяясь и обнажаясь”, ибо судья оказался таков же и одобрил то, что всё ещё в глубине души считалось каждым неправедным. 


\section{Литературоведение}

Пятая определяется непосредственно позицией самого Гоголя, признающего бесовщину, по мнению В. Зеньковского, как «реальность духов зла» ${ }^{33}$.

Общим для всех этих тенденций оказывается некое абсурдистское начало, благодаря которому возникает неожиданный феномен сращивания разрозненных явлений действительности в единое целое, отчего действительность, как это ни парадоксально, кажется ещё более реальной. При этом образы нечисти дают возможность человеку пережить чувство катастрофизма, что отвечает мировосприятию самого Гоголя ${ }^{34}$. Такая черта гоголевского стиля - введение в сюжет трагедийно-абсурдистскойобразностинаосновефантастическойсформировалась в традицию, творчески осмысленную в отечественной и зарубежной литературе.

В целом образы дьявола, воплощённые в рассмотренных нами художественных произведениях, являются не чем иным, как фантазией бунтующего против действительности человека, своеобразной модальностью его духа, имплицитно заложенной в нём самом и выплёскивающейся наружу в зависимости от его эмоционально-психологического состояния ${ }^{35}$.

Итак. По результатам нашего обзора различных трактовок в понимании явлений катастрофизма, выраженных в искусстве посредством деперсонализации личности, нам представляется возможным сделать вывод о том, что история человечества основана на его отношении к трансценденции ${ }^{36}$, неразрывно связанном с моральными устоями самого человечества. При нарушении этих устоев трансценденция в его сознании начинает конкретизироваться и тем самым вочеловечиваться, приобретая реальную силу катастрофического ожидания нравственного возмездия и его свершения.

\section{Список литературы:}

1. Аникст А.А. Творческий путь Гёте. М.: Художественная литература, 1986. 544 с.

2. Бахтин М.М. Творчество Франсуа Рабле и народная культура средневековья и Ренессанса. 2-е изд. М.: Художественная литература, 1990. 544 с.

3. Бинарный архетип // Библиотека учебной и научной литературы. (URL: http://sbiblio.com/biblio/ archive/uvarov_binarniy/00.aspx).

4. Брюсов В.Я. Гипербола и фантастика у Гоголя. (URL: http://az.lib.ru/b/brjusow_w_j/text_0280.shtml).

5. Васильева Г.М. К истории «Замысла о Фаусте» А.С. Пушкина // Наука. Университет. 2000: Материалы Первой научной конференции. Новосибирск, 2000. С. 64-69 // philology.ru: Русский филологический портал. (URL статьи: http://www.philology.ru/literature2/vasilyeva-00.htm).

6. Вулис А.З. Роман М. Булгакова «Мастер и Маргарита». М.: Художественная литература, 1991. 224 с. [Серия «Массовая историко-литературная библиотека»].

7. Гуленко В.В., Молодцов А.В. Введение в соционику. К.: МЗУУП, 1993 // Мы - дуалы: Соционический клуб. (URL статьи: http://dual.com.ua/publ/5-1-0-172).

Антихрист провоцирует последнее разоблачение мира» ([Касаткина Т.] Характерология Достоевского. М.: Наследие, 1996. 335 с. // Журнальный зал: Некоммерческий литературный интернет-проект. (URL статьи: http://magazines.russ.ru:81/novyi_ $\mathrm{mi} / \mathrm{redkol} / \mathrm{kasat} /$ antgog.html). [Дата обращения: 20.11.2012]).

33 Согласно В. Зеньковскому, Гоголя такая реальность в силу его веры в Бога не пугала: “"Связать сатану” может и человек, если обратиться к помощи Божьей; никакой одержимостью демонологией, сознанием всякой дьявольщины в мире Гоголь во второй период жизни не страдал» (Зеньковский В. Русские мыслители и Европа / Сост. П. Алексеева; Подгот. текста и прим. Р. Медведевой; Вступ. ст. В. Жукова и М. Маслина. M., 1997. C. 236).

34 Л. Чернов пишет, что «обладая апокалиптическим зрением, Гоголь видит чёрта как наяву, так сказать предметно: Вия, ведьму, привидений, оживший портрет, так и внутри различных человеческих типажей» (Чернов Л. Гоголь и юродство. (URL: http://www.davidsbuendler.kz/node/179)).
35 В. Карелин пишет, что дьявол - «это душа, которая противится Богу, не выполняет Его законы. То есть дьявол - это сам человек, душа которого под влиянием материального тела стала противником Бога, которая признаёт только материальный мир, которая себя возвысила над законом и потому нарушает божественные законы» (Карелин В. Этот негодный невидимка // Центр «Интеллект». (URL статьи: http:// www.intellectspb.ru/articles/satan.html). [Дата обращения: 21.11.2012]).

36 Об этом писал К. Ясперс: «История философии есть осуществление человеческого сознания в мире, в его отношении к трансценденции. В любое время основанием человеческого бытия является то, в каких богов он верует, какой облик для него принимает трансценденция» (Ясперс К. Всемирная история философии: Введение / Пер. с нем. К. Лошевский. СПб., 2001. С. 74). 


\section{Филология: научные исследования 2(14) • 2014}

8. Зеньковский В.В. Русские мыслители и Европа / Сост. П.В. Алексеева; Подгот. текста и прим. Р.К. Медведевой; Вступ. ст. В.Н. Жукова и М.А. Маслина. М.: Республика, 1997. С. 236. [Серия «Мыслители XX века»].

9. [Касаткина Т.А.] Характерология Достоевского. М.: Наследие, 1996. 335 с. // Журнальный зал: Некоммерческий литературный интернет-проект. (URL статьи: http://magazines.russ.ru:81/novyi_mi/ redkol/kasat/antgog.html).

10. Карелин B.В. Этот негодный невидимка // Центр «Интеллект». (URL статьи: http://www.intellectspb. $\mathrm{ru} / \mathrm{articles/satan.html).}$

11. Корнилова Е.Н. Мифологическое мышление и мифопоэтика западноевропейского романтизма. Дисс. ... д-ра филол. наук. М., 2002. 281 c. (URL: http://www.dissercat.com/content/mifologicheskoe-soznanie-imifopoetika-zapadnoevropeiskogo-romantizma).

12. Крауклис Г.В. Сюжеты и образы Гёте в западноевропейском программном симфонизме XIX в. // Гётевские чтения: 1993 / Под ред. С.В. Тураева. М.: Наука, 1994. С. 159-166.

13. Лейтес Н.С. От «Фауста» до наших дней: Из истории немецкой литературы. М.: Просвещение, 1987. $224 \mathrm{c}$.

14. Лившиц Е.И. Английский контекст творчества Гоголя: Н.В. Гоголь и Ч.Р. Метьюрин. Дисс. ... канд. филол. наук. М., 2001. 221 с. (URL: http://www.dissercat.com/content/angliiskii-kontekst-tvorchestvagogolya-n-v-gogol-i-ch-r-metyurin).

15. Мелетинский Е.М. Заметки о творчестве Достоевского. М.: Российский государственный гуманитарный университет, 2001. 190 с.

16. Николова А.А., Боброва О.И. Образ пошлого чёрта в творчестве Ф.М. Достоевского и А.П. Чехова. (URL: http://web.znu.edu.ua/herald/issues/2008/fil_2008_1_2/2008-26-06/022.pdf).

17. Положенцева Е.В. Культурные ориентиры катастрофического сознания. Дисс. ... канд. филос. наук. Ростов н/Д: Ростовский государственный университет, 2003. 151 c. (URL: http://www.dissercat.com/ content/kulturnye-orientiry-katastroficheskogo-soznaniya).

18. Розанов В.В. Легенда о Великом инквизиторе Ф.М. Достоевского // ВЂхи: Библиотека русской религиозно-философской и художественной литературы. (URL: http://www.vehi.net/rozanov/legenda.html).

19. Романчук Л.А., Щитов Д. Демонизм. Зверь Апокалипсиса: Литературные мифы, версии, реалии / Предисл. А.Д. Михалёва. М.: Мэйлер, 2012. 288 с.

20. Селезнёв Ю.И. В мире Достоевского. М.: Современник, 1980. 376 с. [Библиотека «Любителям российской словесности].

21. Скрягин Л.Н. Тайны морских катастроф. 2-е изд. М.: Транспорт, 1986. 366 с.

22. Сморжко С.Н. Художественная эсхатология в романах Ф.М. Достоевского 1860-1870-х годов. Дисс. ... канд. филол. н. Краснодар, 2007. 201 с. (URL: http://www.dissercat.com/content/khudozhestvennayaeskhatologiya-v-romanakh-fm-dostoevskogo-1860-1870-kh-godov).

23. Тенякова О.М. Катастрофизм как мегатенденция современного цивилизационного развития. Дисс. ... канд. филос. наук. Уфа: Башкирский государственный университет, 2003. 180 c. (URL: http:// www.dissercat.com/content/katastrofizm-kak-megatendentsiya-sovremennogo-tsivilizatsionnogorazvitiya).

24. Уваров М.С. Бинарный архетип // СОФИК: Центр современной философии и культуры имени B.A. Штоффа Санкт-Петербургского Философского общества. (URL статьи: http://sofik-rgi.narod.ru/ avtori/binarniy_arxetyp/01_1.htm).

25. Человекознание // Большой психологический словарь / Сост. Б. Мещеряков, В. Зинченко. М.: ОЛМАПРЕСС, 2004. (URL: http://vocabulary.ru/dictionary/30/word/chelovekoznanie).

26. Чернов Л.С. Гоголь и юродство. (URL: http://www.davidsbuendler.kz/node/179).

27. Чернышевский Н.Г. Эстетические отношения искусства к действительности // Чернышевский Н.Г. Собрание сочинений в 5-и тт. Т. 4. М.: Правда, 1974. С. 5-117.

28. Ясперс К. Всемирная история философии: Введение / Пер. с нем. К.В. Лошевский. СПб.: Наука, 2001. 272 с. [Серия «Слово о сущем»].

29. Ясперс К. Ницше и христианство / Пер. с нем. Т.Ю. Бородай. М.: Медиум, 1994. 116 с. [Московский философский фонд. Серия «Первые публикации в России»]. 


\section{Литературоведение}

\section{References (transliteration):}

1. $\quad$ Anikst A.A. Tvorcheskii put' Gete. M.: Khudozhestvennaya literatura, 1986. $544 \mathrm{~s}$.

2. Bakhtin M.M. Tvorchestvo Fransua Rable i narodnaya kul'tura srednevekov'ya i Renessansa. 2-e izd. M.: Khudozhestvennaya literatura, 1990.544 s.

3. Binarnyi arkhetip // Biblioteka uchebnoi i nauchnoi literatury. (URL: http://sbiblio.com/biblio/archive/ uvarov_binarniy/00.aspx).

4. Bryusov V.Ya. Giperbola i fantastika u Gogolya. (URL: http://az.lib.ru/b/brjusow_w_j/text_0280.shtml).

5. Vasil'eva G.M. K istorii «Zamysla o Fauste» A.S. Pushkina // Nauka. Universitet. 2000. Materialy Pervoi nauchnoi konferentsii. Novosibirsk, 2000. S. 64-69 // philology.ru: Russkii filologicheskii portal. (URL stat'i: http://www.philology.ru/literature2/vasilyeva-00.htm).

6. Vulis A.Z. Roman M. Bulgakova «Master i Margarita». M.: Khudozhestvennaya literatura, 1991. 224 s. [Seriya «Massovaya istoriko-literaturnaya biblioteka»].

7. Gulenko V.V., Molodtsov A.V. Vvedenie v sotsioniku. K.: MZUUP, 1993 // My - dualy: Sotsionicheskii klub. (URL stat'i: http://dual.com.ua/publ/5-1-0-172).

8. Zen'kovskii V.V. Russkie mysliteli i Evropa / Sost. P.V. Alekseeva; Podgot. teksta i prim. R.K. Medvedevoi; Vstup. st. V.N. Zhukova i M.A. Maslina. M.: Respublika, 1997. S. 236. [Seriya «Mysliteli XX veka»].

9. [Kasatkina T.A.] Kharakterologiya Dostoevskogo. M.: Nasledie, 1996. 335 s. // Zhurnal'nyi zal: Nekommercheskii literaturnyi internet-proekt (URL stat'i: http://magazines.russ.ru:81/novyi_mi/redkol/ kasat/antgog.html).

10. Karelin V.V. Etot negodnyi nevidimka // Tsentr «Intellekt». (URL stat'i: http://www.intellectspb.ru/articles/ satan.html).

11. Kornilova E.N. Mifologicheskoe myshlenie i mifopoetika zapadnoevropeiskogo romantizma. Diss. ... d-ra filol. nauk. M., 2002. 281 s. (URL: http://www.dissercat.com/content/mifologicheskoe-soznanie-i-mifopoetikazapadnoevropeiskogo-romantizma).

12. Krauklis G.V. Syuzhety i obrazy Gete v zapadnoevropeiskom pro-grammnom simfonizme XIX v. // Getevskie chteniya: 1993 / Pod red. S.V. Turaeva. M.: Nauka, 1994. S. 159-166.

13. Leites N.S. Ot «Fausta» do nashikh dnei: Iz istorii nemetskoi literatury. M.: Prosveshchenie, 1987. 224 s.

14. Livshits E.I. Angliiskii kontekst tvorchestva Gogolya: N.V. Gogol' i Ch.R. Met'yurin. Diss. ... kand. filol. nauk. M., 2001. 221 s. (URL: http://www.dissercat.com/content/angliiskii-kontekst-tvorchestva-gogolya-n-v-gogol-ich-r-metyurin).

15. Meletinskii E.M.Zametki o tvorchestve Dostoevskogo. M.: Rossiiskiigosudarstvennyi gumanitarnyi universitet, 2001. $190 \mathrm{~s}$.

16. Nikolova A.A., Bobrova O.I. Obraz poshlogo cherta v tvorchestve F.M. Dostoevskogo i A.P. Chekhova. (URL: http://web.znu.edu.ua/herald/issues/2008/fil_2008_1_2/2008-26-06/022.pdf).

17. Polozhentseva E.V. Kul'turnye orientiry katastroficheskogo soznaniya. Dis. ... kand. filos. nauk. — Rostov n/D: Rostovskii gosudarstvennyi universitet, 2003. - 151 s. URL: http://www.dissercat.com/content/kulturnyeorientiry-katastroficheskogo-soznaniya.

18. Rozanov V.V. Legenda o Velikom inkvizitore F.M. Dostoevskogo // VЂkhi: Biblioteka russkoi religioznofilosofskoi i khudozhestvennoi literatury. (URL: http://www.vehi.net/rozanov/legenda.html).

19. Romanchuk L.A., Shchitov D. Demonizm. Zver' Apokalipsisa: Literaturnye mify, versii, realii / Predisl. A.D. Mikhaleva. M.: Meiler, 2012. $288 \mathrm{~s}$.

20. Seleznev Yu.I. V mire Dostoevskogo. M.: Sovremennik, 1980. 376 s. [Biblioteka «Lyubitelyam rossiiskoi slovesnosti].

21. Skryagin L.N. Tainy morskikh katastrof. 2-e izd. M.: Transport, 1986. 366 s.

22. Smorzhko S.N. Khudozhestvennaya eskhatologiya v romanakh F.M. Dostoevskogo 1860-1870-kh godov. Diss. ... kand. filol. n. Krasnodar, 2007. 201 s. (URL: http://www.dissercat.com/content/khudozhestvennayaeskhatologiya-v-romanakh-fm-dostoevskogo-1860-1870-kh-godov).

23. Tenyakova O.M. Katastrofizm kak megatendentsiya sovremennogo tsivilizatsionnogo razvitiya. Diss. ... kand. filos. nauk. Ufa: Bashkirskii gosudarstvennyi universitet, 2003. 180 s. (URL: http://www.dissercat.com/ content/katastrofizm-kak-megatendentsiya-sovremennogo-tsivilizatsionnogo-razvitiya). 


\section{Филология: научные исследования 2(14) • 2014}

24. Uvarov M.S. Binarnyi arkhetip // SOFIK: Tsentr sovremennoi filosofii i kul'tury imeni V.A. Shtoffa SanktPeterburgskogo Filosofskogo obshchestva. (URL stat'i: http://sofik-rgi.narod.ru/avtori/binarniy_ arxetyp/01_1.htm).

25. Chelovekoznanie // Bol'shoi psikhologicheskii slovar' / Sost. B. Meshcheryakov, V. Zinchenko. M.: OLMAPRESS, 2004. (URL: http://vocabulary.ru/dictionary/30/word/chelovekoznanie).

26. Chernov L.S. Gogol' i yurodstvo. (URL: http://www.davidsbuendler.kz/node/179).

27. Chernyshevskii N.G. Esteticheskie otnosheniya iskusstva k deistvitel'nosti // Chernyshevskii N.G. Sobranie sochinenii v 5-i tt. T. 4. M.: Pravda, 1974. S. 5-117.

28. Yaspers K. Vsemirnaya istoriya filosofii: Vvedenie / Per. s nem. K.V. Loshevskii. SPb.: Nauka, 2001. 272 s. [Seriya «Slovo o sushchem»].

29. Yaspers K. Nitsshe i khristianstvo / Per. s nem. T.Yu. Borodai. M.: Medium, 1994. 116 s. [Moskovskii filosofskii fond. Seriya «Pervye publikatsii v Rossii»]. 